\section{Воена хералдика}

Потребата за обележување (китење и украсување) е стара колку и човештвото. Преку накитот и украсите човекот сака да покаже припадност, надмоќ, сталеж, навики. Воените украси и накит претставуваат голем дел од таа потреба да се различи своето од туѓото, пријателот од непријателот, водачот од водените. Се чини војната во сета своја грозоморност се јавува како двигател за создавање симболи.

Од древни извори дознаваме за тоа како биле облечени и украсени воините, водачите, главатарите. Знаеме за древногрчките хоплити и нивните штитови украсени со различни амблемни претстави на воловска глава, змија, утка, трозабец, делфин и др., за орелот како симбол на древноперсиската војска. Особено интересни се римските signa militaria претставени преку различен vexillum и легионската Aquila како и различните видови coronae како обележја за постигнати воени успеси. Од ова време доаѓаат и податоците дека древномакедонската фаланга чекорела sub signum и signa infestis...

Првите грбови, всушност, претставуваат лична ознака на благородник од едно време кога благородништвото пред сѐ е војничко, т.е. воена аристократија. Крстоносните војни ќе предизвикаат промена во начинот на војување и видовите оружја и со тоа и на грбот како основен хералдички елемент ${ }^{2}$. Во тоа феудално општество носењето на ознаките на даден благородник претставувало и преданост до смрт. Таков пример е династичка борба меѓу црвените и белите рози во Англија (1455-1485 г. $)^{3}$.

Создавањето масовни војски на државна и национална основа во XIX век ќе предизвика уште една стапка во развојот на ознаките ${ }^{4}$ и воената хералдика, чии последици се очевидни и денес во многу од тие армии. Во прв ред тука се знаците за припадност кон дадена војска (во државна смисла), ознаките за припадност кон дадена единица (чета, баталјон, полк, дивизија), ознаките за стручност, помината обука, добро поведение, припадност по род и вид војска итн. Така се појавуваат на сцена кокардите во национални бои или со државниот или монархистичкиот грб, а грбовите на одделни градови, околии, области се користат за ознаки на поединечни единици разместени на соодветното место 5 . Таков е примерот со шведската, финската, данската војска. Осознавајќк ја огромната важност на ознаките од секаков вид истовремено со нивниот забрзан развој ќе се појават и специјализирани служби задолжени за нивна изработка и одобрување.
The need for marking (decoration and embellishment) is as old as humanity. By decoration and embellishment one shows background, superiority, class, habits. The military insignias are a major part of the means to distinguish ours from theirs, a friend from foe and the leader from the led. It seems war in all its ferocity is an engine for the creation of symbols.

From ancient sources we have learned how the ancient warriors and chieftains were dressed and decorated. We know of the ancient Greek hoplite and their shields decorated with different emblems like the ox head, snake, owl, trident, dolphin etc, and the eagle like a symbol of the ancient Persian army. Especially interesting are the Roman Signa militaria represented by the different vexillums and the legions Aquila, and the different types of coronae, symbols of military success. From this age comes the knowledge that the ancient Macedonian phalanx marched sub signum and signa infestis...

The first coats of arms were essentially personal insignia of noblemen in a time when the nobility was exclusively military aka military aristocracy. The Crusades caused a major change in the methods of warfare, arms used and by that a change to the coat of arms as a primary heraldic element ${ }^{2}$. In that feudal society carrying the insignia of a nobleman meant loyalty unto death. Such an example is the dynastic struggle between the White and Red Roses in England (1455-1485) ${ }^{3}$.

The creation of mass armies in the XIX cen-

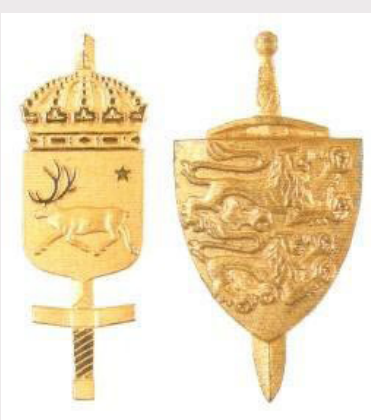

Данска и Шведска градна значка I

Danish and Swedish pins tury on state and national grounds caused another step in the development of insignia ${ }^{4}$ and military heraldry, consequences which are still obvious in many of the same armies. Primarily those are the insignia of belonging to an army (in a national sense), insignia of belonging to a unit (company, battalion, brigade, division), skill badges, badges for completed training, good conduct, service branch badges etc; And so appeared the cockades in national colors or with the coat of arms of the monarch. Meanwhile the coats of arm of towns, regions, prefectures were used as insignia for units situated in them $^{5}$. This is the case with the Swedish, Finnish and Danish armies. Realizing the importance of any kind of insignia, simultaneously with their fast development 
Во САД тоа е „US Army Institute of Heraldry“, во Франција историската служба при копнената војска, во Шпанија институтот за историја и воена култура.

Од современа воено-хералдичка гледна точка особено интересни се грбовите на копнените војски на САД, Шпанија и на Португалија. Овие ознаки се хералдички грбови во вистинска смисла на зборот (во американскиот случај се работи за среден грб, а кај Шпанците и Португалците за полни хералдички достигнувања). Според армиските регулативи, сите полкови и некои други единици на американската копнена војска можат да имаат свој сопствен грб ${ }^{6}$. Грбот се состои од штит, челенка и мото/девиза. Ова достигнување се користи како основа за создавање на т.н. „distinctive unit insignia“ (DUI) ${ }^{7}$, ознака носена од сите припадници на плокот/единицата на нивните работни униформи. Друга намена на грбот е негово истакнување на полковиот стег „соlors“8.

Грбовите на шпанската „Ejercito de tierra“ ce едни од најубавите и најбогатите примери на воено-хералдички достигнувања. Во себе тие вклучуваат повеќе хералдички елементи: а) штит, б) одликувачки знаци за род расположени во вид на кос крст зад штитот, в) шпанска царска круна над штитот, г) добиени воени одликувања (ордени и медали) под штитот, ако единицата е носител на највисокото можно воено одликување т.н. „laureada“, тогаш таа се појавува како ловоров венец украсен со сечива, д) боен клик „сri-de-guerre“, ѓ) име на единицата ${ }^{9}$. На ваков начин се добива едно моќно, неверојатно естетско и историски потковано средство за обосебување. Значајни и интересни се хералдичките достигнувања и на италијанската, руската, германската војска.

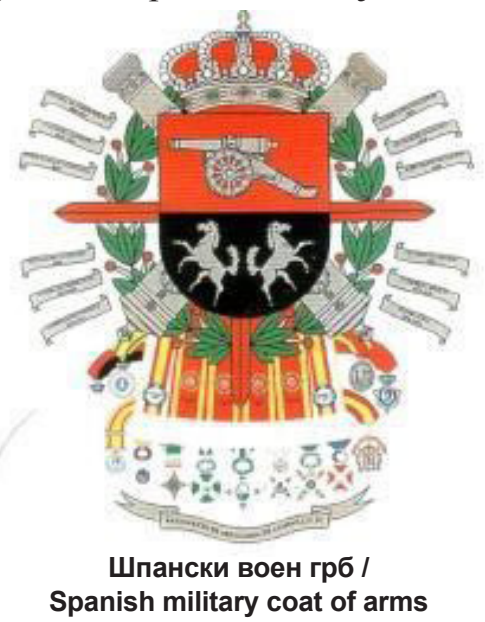

Патиштата на военото дело и симболиката се преплетуваат во една прекрасна нишка налик на онаа генетската во која е запишан човечкиот бит, а тоа и' обезбедува сигурност на воената хералдика дека ќе биде дел од таа нишка и во десетлетијата што доаѓаат. Нам ни останува само да се надеваме дека скоро ќе дојде она време кога македонската војска ќе добие ознаки достојни на нејзината задача, подвизи и успеси со кои ќе може да се натпреварува со големите светски сили онака како што тоа го правела и прави на бојното поле. specialized services appeared authorized for approving and creating them. In the US there is the Institute of Heraldry, in France the historical department of the Armée de Terre and in Spain Instituto de Historia y Cultura Militar.

From a modern point of view most interesting are the coats of arms of the Spanish, Portuguese and US armies. These insignias are coats of arms in a classical heraldic sense (in the case of the US Army a middle achievement and in the Spanish and Portuguese case a full achievement). According to the US Army Regulations all regiments and some other units of the Army may own coat of arms $(\mathrm{CoA})^{6}$. The CoA consists of a shield, a crest and motto. This achievement is used as a basis for the creation of the distinctive unit insignia (DUI) ${ }^{7}$, insignia worn by all the members of the unit on their uniforms. Other usage of the CoA is for the regimental colors 8 .

The coats of arms of the Spanish Ejercito de Tierra are one of the finest and richest examples of military heraldic achievements. They incorporate a few heraldic elements: a) a shield, b) insignia of branch service positioned as a saltier behind the shield, c) Spanish royal crown over the shield, d) military decorations (orders and medals) under the shield, if the unit has the highest military decoration, the "laureada", than it appears as a laurel wreath decorated with blades, e) motto „cride-guerre", f) the name of the unit'. In this manner a powerful, amazingly aesthetic and historically precise device of identification is created. The achievements of the Russian, German and Italian armies are very interesting and important as well.

The paths of military profession and of symbolism came across in a beautiful thread like the one of the human gene and by that it secures a certainty that the military heraldry will be part of it in the decades to come. It leaves as only hope that in the years to come the Macedonian army will acquire the insignia appropriate to its assignment, achievements and success with which it can compete with the Great Powers as it has done and it still does on the battlefield.

\begin{tabular}{l}
\hline Наде Проева, СТУДИИ ЗА АНТИЧКИТЕ МАКЕДОНЦИ, \\
Скопје 1997 стр. 113 \\
2 Јован Јоновски, ХЕРАЛДИЧКИ БУКВАР \\
3 Стивен Слейтер, ГЕРАЛЬДИКА ИЛЛЮСТРИРОВАННАЯ \\
ЭНЦИКЛОПЕДИЯ, Москва 2005, стр. 160 \\
4 Guido Rosignoli,THE ILLUSTRATED ENCYCLOPEDIA OF \\
MILITARY INSIGNIA OF THE 20TH CENTURY, стр. 7 \\
5 Стивен Слейтер, ГЕРАЛЬДИКА ИЛЛЮСТРИРОВАННАЯ \\
ЭНЦИКЛОПЕДИЯ, Москва 2005, стр. 161 \\
6 ТІОН official web-site \\
7 ...ibidem \\
8 ...ibidem \\
9 Стивен Слейтер, ГЕРАЛЬДИКА ИЛЛЮСТРИРОВАННАЯ \\
ЭНЦИКЛОПЕДИЯ, Москва 2005, стр. 163
\end{tabular}

1 Наде Проева, СТУДИИ ЗА АНТИЧКИТЕ МАКЕДОНЦИ, Скопје 1997 стр. 113

2 Јован ЈоНовски, ХЕРАЛДИЧКИ БУКВАР

3 Стивен Слейтер, ГЕРАЛЬДИКА ИЛЛЮСТРИРОВАННАЯ ЭНЦИКЛОПЕДИЯ, Москва 2005, стр. 160

4 Guido Rosignoli,THE ILLUSTRATED ENCYCLOPEDIA OF MILITARY INSIGNIA OF THE 20TH CENTURY, стр. 7

5 СТивен СлеЙтер, ГЕРАЛЬДИКА ИЛЛЮСТРИРОВАННАЯ ЭНЦИКЛОПЕДИЯ, Москва 2005, стр. 161

$6 \mathrm{TIOH}$ official web-site

7 ...ibidem

8 ...ibidem

ЭНЦИКЛОПЕДИЯ, Москва 2005, стр. 163 